\title{
The Impact of Fiscal Policy on the Economic Growth of Jordan
}

\author{
Abdullah Ali Al-Masaeed ${ }^{1,2}$ \& Evgeny Tsaregorodtsev ${ }^{3}$ \\ ${ }^{1}$ Ph.D student, Department of Economics and Finance, Mari State University, Russia \\ 2 Part-time Lecturer, Department of Finance and Business Economics, Faculty of Finance, Business and \\ Management, Al-Al Bait University, Jordan \\ ${ }^{3}$ Prof., Department of Economics and Finance, Mari State University, Russia \\ Correspondence: Abdullah Ali Al-Masaeed, Department of Finance and Business Economics, Faculty of Finance, \\ Business and Management, Al-Al Bait University, Jordan. E-mail: almasaeed.abdullah@yahoo.com.ph
}

Received: February 28, 2018

Accepted: September 28, 2018

Online Published: September 30, 2018

doi:10.5539/ijef.v10n10p145

URL: https://doi.org/10.5539/ijef.v10n10p145

\begin{abstract}
The present study examined the impact of fiscal policy measured by (Government expenditure, Government revenues, internal public debt, external public debt) in addition to exports and inflation factors on the Jordanian GDP growth for the period 1990-2010. The study used multiple linear regression and least squares method (OLS) to test the study hypotheses. The study found that government expenditure, exports and government revenues has a positive and significant impact on the Jordanian GDP growth, and negative and significant impact on the Jordanian GDP growth. The study found that external public debt has a negative but not significant impact on the Jordanian GDP growth.
\end{abstract}

Keywords: fiscal policy, government expenditure, government revenues, internal public debt, external public debt, inflation, GDP growth, multiple linear regression, least squares method (OLS)

\section{Introduction}

Fiscal policy plays a significant role in an economic policy due to its ability to realize goals aimed at by a national economy. Its tools are considered one of the main economic tools to achieve economic growth and overcome obstacles to economic stability. In addition to its distributional and specialist effects, fiscal policy has stability-inducing effects such as government spending and taxes which influence aggregate demand, thereby affecting overall economic variables and economic growth.

The importance of fiscal policy emanates from the fact that public spending is considered the prime drive for economic activity of a country by influencing the level of aggregate demand and hence economic growth. Public revenues serve as the main source of income for a country while public debt is part of the government's spending, whether internal or external.

Public finance is the chief tool implemented by governments to achieve economic, social, and political goals. Fiscal policy, therefore, has acquired a cardinal importance in current economic systems. In Jordan, there was a growing need for a sound fiscal policy early on that has started growing increasingly since 1989 following the Jordanian currency depreciation.

Jordan's first economic reform program was in place until the first Gulf War in 1990. In 1992, the program was resumed and entered its second phase as the second economic reform program and lasted three years, followed by a third reform program until 1998.

Jordan's economic performance was profoundly affected in 1998 as a result of the drop in oil prices. It had an adverse effect on trade-offs with oil producing Arab countries as well as expatriates transfers.

Jordan's economy was also affected by sanctions imposed on Iraq and the successive crises with the United Nations, as well as the burden of external public debt. These factors deeply affected the performance of the general budget, balance of payment, and the level of economic activity. In light of this, the efforts of economic reform from 1989-1998 were evaluated and there was a need to draw up a medium-range economic reform program that spanned the period 1999-2001.

It aimed at addressing drawbacks in the former program so that it can reinforce national economic reform in all its 
aspects and extend its scope to encompass various levels such as combining efforts to combat poverty and unemployment.

Within this context, the main features of a national program for economic reform were identified. The program's main objectives (1999-2001) aimed at realizing a gradual increase in economic growth rates, controlling inflation rates, enhancing the Kingdom's reserves of foreign currency, maintaining the stability of Jordanian Dinar exchange rates, and reducing the deficit of the government budget as a ratio of GDP. In addition, it sought to proceed with structural adjustments that include implementing social security packages to alleviate poverty and unemployment, liberalization of foreign trade, and privatization of companies and sectors to give way to the private sector for wider participation in economic activity and attraction of foreign investments. In order to move forward with the reform process, Jordan signed a two-year agreement with the International Monetary Fund for a new program on economic reform until 2004. The program aimed at sustainable economic growth that positively and directly affected the living standards of citizens by following through with structural adjustments and relevant public policies. It further aimed at reducing the budget deficit as a ratio of GDP, and providing sources of funding needed for the program of economic and social reform.

\subsection{Problem}

A fiscal policy is a state's most important tool for controlling the national economy of both developing and developed countries. The state achieves economic goals set through this policy. Jordan has adopted various policies in the study period (1990-2010). The study problem centers on answering this question:

What is the effect of the fiscal policy on economic growth in Jordan, measured against government spending, revenues, internal public debt, and external public debt?

The study raises other sub-questions:

1) Does public spending affect economic growth in Jordan?

2) Do public revenues affect economic growth in Jordan?

3) Does internal public debt affect economic growth in Jordan?

4) Does external public debt affect economic growth in Jordan?

Considering the correlation between government revenues and internal and external public debt on the one hand and public spending on the other, two patterns were applied to overcome multicollinearity and add some explanatory variables such as exports, inflation, and public spending. However, the changes in economic growth attributed to public spending were excluded from the study. Therefore, the study asks:

1) Do exports affect economic growth in Jordan?

2) Does inflation affect economic growth in Jordan?

\subsection{Objectives}

The study aims at:

1) Exploring the effect of the fiscal policy for the period of 1990-2010, particularly the tools, on economic growth in Jordan.

2) Emphasizing the theoretical and practical aspects of analyzing the fiscal policy and their effect on economic growth.

3) Exploring a fiscal policy tool that may achieve the best economic growth and implementing it in Jordan.

4) Drawing up recommendations to maximize the effectiveness of the fiscal policy in Jordan based on the resulting indicators and results of this study.

\subsection{Study Hypotheses}

1) There is a statistically significant effect of public spending on economic growth.

2) There is a statistically significant effect of government revenues on economic growth.

3) There is a statistically significant effect of internal public debt on economic growth.

4) There is a statistically significant effect of external public debt on economic growth.

5) There is a statistically significant effect of exports on economic growth.

6) There is a statistically significant effect of inflation on economic growth. 


\subsection{Significance of the Study}

1) Emphasizing the role of a fiscal policy and its tools as a main incentive for economic growth.

2) Focusing on a key issue in macroeconomics, namely economic growth, and the role of fiscal policy in realizing it, and focusing on the role of the state in economics by controlling indicators of macroeconomics, on the one hand, and achieving economic growth, on the other.

3) Highlighting the significance of the fiscal policy itself, considering that government spending is the main impetus for a state's economic activity and revenues as the main financial source.

\section{Literature Review}

The effects of fiscal policy on economic growth vary depending upon the resources of the country, space, population, government expenditure, and revenues. Ben Bouzian and Chibi ( 2007 ) show that public expenditure created a positive effect on real GDP in the short run, but in the medium run, a negative effect prevailed. The effect of this structural shock on inflation rates, interest, consumption, and volume of public expenditure was positive. Qabbor (2008) explores the role of fiscal policy in addressing fiscal imbalances and reveals that there is a correlation between public expenditure and public revenues resulting from oil revenues on the one hand and economic growth on the other. By identifying techniques and standards of fiscal policy in addressing fiscal and economic imbalances in developing countries and their solutions, Khalot (2004) highlights the role that fiscal policy plays in economic activity and the achievement of coordination between the tools of fiscal and monetary policies. Priority should be given to any of the two policies without disregarding the other, considering preventing conditions; tax reform over foreign trade through tax abatement over exports as a step to abolish them and tax abatement over. Al- Issa (2006) applied a stationary test (unit root test) and Johansen co-integration test for the GDP of Saudi Arabia, UAE, and Kuwait that indicate that there is a long term correlation between the variables and that they occur concurrently having the same behavior. The error correction test results showed that FEC (forward error correction) has a negative static significance. The last two tests showed the positive influence of public expenditure on GDP in the short and long terms for the countries concerned. Darawsi (2005) looks into the effect of public spending and deductions on economic balance in Algeria and the GNP to find the optimal fiscal policy that realizes the main economic goals. External shocks which particularly involve disturbances in oil prices in addition to exchange rates and economic policies that were adopted in the past years that brought about a budget deficit show that Algeria had long been suffering from economic imbalances. A Granger test can be applied to show the relation between public expenditure as a ratio of the GDP, the ratio of employment, and the ratio of GDP growth (Chibi \& Bataher, 2010). Public expenditure did not lead to either economic growth or unemployment. The effect of public investment as a ratio of GDP on private investment as a ratio of GDP can be looked into by adopting the Johansen's co-integration test. It was revealed that there was a negative response of private investment ratio in public investment ratio.

Determinants to public debt in Jordan such as public budget deficit, resources gap, and real exchange rate have a great influence on the volume of external public debt and have statistically significant co-efficient with the real exchange rate (Bader \& Maqableh, 2009). These factors do not only undermine the ability to debt payment, but also create an excess demand to internal debt. Batyneh (2009) examines the interrelation between government revenues and spending in Jordan (1980-2008) by adopting the co-integrated test and error correction test. The causative relation which extends from government expenditure to revenues showed a preference to decrease expenditure to lessen government deficit, a concept known as an austerity policy and reduction of government expenditure.

Time series evidence explores the dynamic effects of fiscal policy on macroeconomic indicators (Shahid \& Naved, 2009). Through adoption of modern econometric techniques, auto regressive distribute lag ARDL, fiscal deficit exerts a negative effect on economic growth in the long run. The impact of a fiscal policy on economic growth is much stronger on an exchange rate channel. An expansionary fiscal policy takes a long time to affect economic growth. Government investment expenditure exerts a strong influence over macroeconomic activities. A shock in government investment expenditure has a positive effect on private investment, and this indicates that public and private sectors investments are complementary. A shock in productive expenditure also has a positive and great impact on private consumption. Both private investment and capital exerted considerable impact on the income per capita in Kenya (Amanja \& Morrissey, 2005). Equally important, consumption expenditure and government investment play a significant role in the presence of real growth in income per capita in Kenya. The government should reduce nonproductive expenditure in order to support government investment, being productive.

The relation between government expenditure and economic growth assesses the validity of Wagner's law (Dilrukshini, 2002), the law of increasing public expenditure, that any increase in GDP results in government 
expenditure growth, increasing government posts leads to increasing expenditure and increasing expenditure increases the relativity in the public sector. Considering various variables, namely public spending and government revenues, Benos (2009) finds that increasing spending on infrastructure had a positive impact on economic growth, government spending on defense reflected positively on per capita income growth, and imposing distortionary taxes decreased growth. With Government spending on capital (education, health, housing, social security, luxuries, environment, entertainment, culture, and religion), social security meagerly impacted per capita growth. Out of various variables, interest rate, investment and tax spending, budget deficit, and government consumption, Ocran (2011), using various standard models such as VAR, finds that government consumption spending has a great positive impact on economic growth. Gross fixed capital has a positive impact on economic growth but less than that which government consumption spending has. Tax revenues have a positive impact on economic growth, but fiscal deficit seems to have a meager impact on economic growth outcomes.

Long-term effects of fiscal policy are measured adopting unrestricted VAR models with variables such as public spending, public consumption, direct and indirect taxation, and public investment (Preiera \& Roca, 2011). The effects of policies within Keynesian paradigm for public expenditure, public consumption, public investments, and direct taxation with public investment were particularly and considerably positive. Non- Keynesian effects, on the other hand, were predominately negligible. Effects on the practical level showed that any cuts in public consumption were accompanied by an increase in indirect taxation, which would be the most desirable instrument to consolidate the fiscal situation in Portugal. Usman and Nurdeen (2010) considered variables including expenditure on health, education, transportation, telecommunications, agriculture, field programs, and inflation. Tests applied to observe this relationship included the unit root test and regression analysis test. Government spending on education, field programs, and recurrent expenditures had a negative impact on economic growth. Increasing spending on transportation, telecommunications, and health led to an increase in economic growth.

\section{Method}

Research is governed by many stages starting with identifying the problem, posing the hypothesis, collecting and analyzing data, and making recommendations. Research papers are governed by many factors including the nature of the problem and identifying the research approach as a set of scientific theoretical principles on which addressing an issue is based (Helmi et al., 1999).

\subsection{Variables}

The study includes a dependent variable and six independent variables, as the plan below shows.

\subsubsection{Dependent Variable}

Economic growth in Jordan.

\subsubsection{Independent Variables}

Public spending, public revenues, internal public debt, external public debt, exports, and inflation.

To realize the study objectives in light of its nature, significance, concepts, and hypotheses, to answer its questions and test the validity of the aforementioned hypotheses based on the data collected, the following approaches have been adopted:

- Analytical Descriptive Approach to analyze the data collected about the problem (Askar et al., 1992).

- Standard Analytical Approach to examine the hypotheses.

\subsection{Data Sources}

Secondary data: is the data that were collected by other researchers or projects which are generally less costly and save time (Najjar et al., 2008).

Preliminary data: is the official data released by the Ministry of Finance as well as the Central Bank, Department of Statics in consensus with the IMF, and the internet.

\subsection{Statistical Methods}

After data collection and examination, relevant statistical tests were determined through incorporating inputs and economic data in a regression analysis known as E-views. This is to find answers to the study questions, test hypotheses, and obtain results and recommendations. The tests are: Unit Root Test, Co- integration Test, Multiple Linear Regression Test, and Validity Test that includes:

- Homogeneity Test;

- Serial Correlation Test; 
- Normal Distribution Test.

\subsection{Standard Model}

Due to the correlation of public revenues and internal and external public debts on the one hand and public expenditure on the other, Multiple Regression Test was incorporated in two models to avoid the problem of multicollinearity.

\section{First model}

$$
E G_{i}=\alpha+\beta_{1} P E_{i}+\beta_{2} X_{i}+\beta_{3} I N_{i}+\varepsilon_{i}
$$

EG: Economic Growth;

IN1: Inflation;

PE1: Public Expenditure;

$\mathrm{E}_{1}$ : Random error;

$\mathrm{X}_{1}$ : Exports.

\section{Second model}

$$
E G_{i}=\alpha+\beta_{1} P R_{i}+\beta_{2} E D_{i}+\beta_{3} I D_{i}+\varepsilon_{i}
$$

$\mathrm{EG}_{1}$ : Economic Growth;

$\mathrm{PR}_{1}$ : Public Revenues;

$\mathrm{ED}_{1}$ : External Debt;

$\mathrm{ID}_{1}$ : Internal Debt;

$\mathrm{E}_{1}$ : Random Error.

\subsection{Tests and Validity}

Based on data obtained and studies, Qabbour (2008), Abo Tayeh and Mustafa (2011), and the Economic Theory, the variables of the study were identified. Statistical tests were employed using E-views to answer the questions of the study, examine hypotheses, and form results and recommendations. Tests were presented after designing the study models to illustrate steps for each model separately.

3.6 Models of the Study

Due to the correlation between government revenues and internal and external debts on the one hand and public expenditure on the other, multiple regressions were carried out in two models to avoid the problem of multicollinearity.

Model (1)

$$
E G_{i}=\alpha+\beta_{1} P E_{i}+\beta_{2} X_{i}+\beta_{3} I N_{i}+\varepsilon_{i}
$$

In which:

$\mathrm{EG}_{1}$ : Economic Growth;

$\mathrm{PE}_{1}$ : Public Expenditure;

$\mathrm{X}_{1}$ : Exports;

$\mathrm{IN}_{1}$ : Inflation;

$\mathrm{E}_{1}$ : Random Error.

Model (2)

$$
E G_{i}=\alpha+\beta_{1} P R_{i}+\beta_{2} E D_{i}+\beta_{3} I D_{i}+\varepsilon_{i}
$$

In which:

EG1: Economic Growth;

$\mathrm{PR}_{1}$ : Public Revenues;

$\mathrm{ED}_{1}$ : External Debt;

$\mathrm{ID}_{1}$ : Internal Debt;

E1: Random Error. 


\section{Statistics and Data Analysis}

\subsection{Descriptive Statistics}

The statistics were used to outline data reasonably and practically as an easy way to understand and illustrate the study. They were included in a table for two models. Table 1 shows the highest and the lowest values of the variables with the median, arithmetic mean, and standard deviation for all data (see table 1 below).

Table 1. Median, mean, and standard deviation of the variables

\begin{tabular}{cccccc}
\hline Variable & Highest value & Lowest value & Median & Mean & Standard Deviation \\
\hline Economic Growth & 14.351 & -0.28 & 4.485 & 5.179 & 3.23 \\
Internal debt & 7980 & 914 & 1235 & 2316.381 & 2095.09 \\
External debt & 5510 & 3640 & 5044 & 4913.8095 & 494.37 \\
Public Revenues & 4690 & 1015 & 1802 & 2324.4762 & 1250.54 \\
Public Expenditure & 5911 & 1222 & 2028 & 2744.095 & 1517.49 \\
Exports & 5633 & 706 & 1347 & 2209.62 & 1523.51 \\
Inflation & 16.192 & -0.672 & 3.365 & 4.4145 & 4.12055 \\
\hline
\end{tabular}

Note. Figures presented are in million Dinars.

Source: Researcher collection E-views.

Table 1 shows that during the period 1990 to 2010:

- The mean of economic growth was 5.179 with a standard deviation of 3.23. The highest value was 14.351 while the lowest was -0.28 .

- Internal debt mean was 2,316.381 with a standard deviation of 2,095.09. The highest value was 79,800 and the lowest was 914 .

- External debt mean was 4,913.8095 with a standard deviation of 494.37. The highest value was 5,510 while the lowest was 3,604 .

- The mean of public expenditure was $2,744.095$ with a standard deviation of $1,517.49$. The highest value was 5,911 and the lowest was 1,222 .

- Public revenues mean was 2,324.4762 with a standard deviation of $1,250.54$. The highest value was 4,690 and the lowest was 1,015.

- Exports mean was 2,209.62 with a standard deviation of 1,523.51. The highest value was 5,633 and the lowest was 706 .

- Inflation mean was 3.365 with a standard deviation of 4.12055. The highest value was 16.192 and the lowest was -0.672 .

The data helped identify the extent to which independent economic variables may affect the dependent variables, the highest and lowest values, the distance between the data and the mean, its dispersion as indicated by standard deviation, and the mean of the variables which shows its high or low value.

Results of the econometric model, hypotheses test, coefficients among variables (economic growth, internal and external debts, public revenues, public expenditure, exports, and inflation) during the period 1990 to 2010 are also included.

The unit root of the aforementioned extracted variables, data stability, and auto correlation coefficients of the examined variables revealed that there is a correlation between public revenues and internal and external debts on the one hand and public expenditure on the other. As a result, multiple linear regressions were carried out in two models to avoid the issues of multicollinearity between the said variables. Therefore, two standard models were adopted to look into the effect of a fiscal policy on economic growth in Jordan during the period 1990 to 2010.

Due to the developments in metroeconomics and time series analyses, statistical features of time series become concerned with the stationary or non-stationary of these series, especially following the Plosser and Nelson study (1982) in which they confirmed that most time series in the USA have unit root and hence are non-stationary. It follows then that applying traditional metroeconomic methods to non-stationary data will lead to inaccurate or fake results. The present study applies unit root tests, such as the Dicky-Fuller test, to detect whether the data obtained from the variables are stationary or non-stationary. 
The present study sought to find a long term relationship between the variables of the study. To this end, the co-integration test was carried out to show whether there was a long-term relationship or not. Having ascertained a unit root in a time series, it can be detected whether it has a trend or not, which can be found in the Dicky-Fuller test.

Lag periods are identified to find out whether a variable has a trend that it can be incorporated within various regression processes as when a trend found in the data of variables in an economic model results in the impact of this trend on the coefficients of the other variables. If a time series proves non-stationary at a level, the first difference is considered and a stationary test is carried out again. If it proves non-stationary, the second difference is considered, and so forth, until the time series can be described as stationary. Regularly, stationary time series are not obtained in lag periods higher than the first rate.

Consequently, the augmented Dicky-Fuller test for the first lag may not be convenient to show stationary time series. The study uses one type of augmented Dicky-Fuller test that provides the higher lag.

\subsection{Unit Root Test}

Economic data are frequently characterized by having structural changes that affect stationary time series. Therefore, identifying a stationary degree is vital before any test for relations between variables is carried out. This entails non-stationary and complete data at the same time (If the first difference of random variables is stationary, the original series will be an integration of order 1). If the series is stationary following the second differences (first differences are for first differences only), the first series will be an integration of order 2, i.e., 1(2). Hence, if the original series is stationary, it will be considered an integration of order zero, which does not have a unit root i.e. $1(0)$. Generally, a series is an integration of order (d) if it is stable at difference level (d); it has a (d) unit root.

A number of studies (Nelson \& Plosser, 1982) maintain that most time series have a unit root. A study carried out by Stock and Watson (1989) revealed that the level of these time series is non-stationary. This means that the mean and the variance of the variables are dependent throughout time having a unit root in any time series. This may lead to a spurious correlation, standard analysis, and influence problems.

Many tests can be carried out to detect the existence of a unit root to determine a stationary time series, such as a Phillips and Perron test (PP) (1988) and augmented Dickey-Fuller test (ADF). A PP may be different from an $\mathrm{ADF}$ in that the former does not have lag values of differences which take into consideration correlation of first differences in a time series by using non - parametric correction. It also allows having a non-zero mean and linear time trend.

In this study, augmented Dicky-Fuller tests were adopted to carry out stationary tests and to test stationary variables (Gujarati \& Porter, 2009) along with traditional tests and stationary time series like Dicky-Fuller and Phillip Perron to test unit root hypothesis (hence, non-stationary time series) as a null hypothesis.

\subsection{Augmented Dicky-Fuller Test}

This test is based on unit root hypotheses in a given time series $\left(\mathrm{Y}_{1}\right)$ drawn from the following formula (Guajarati and Porter, 2009). This equation can be formed according to the first difference in which P is equal to $\mathrm{B}_{-} 1$ as follows:

$$
\begin{gathered}
Y_{\mathrm{t}}=\beta Y_{t-1}+U_{t},-1 \leq \beta \leq 1 \\
Y_{t}-Y_{t-1}=\beta Y_{(t-1)}-Y_{(t-1)}+U_{(t)} \\
\Delta Y_{t}=\rho Y_{(t-1)}+U_{(t)}
\end{gathered}
$$

The test considers that random error $\left(V_{t}\right)$ is subject to white noise disturbances. It examines a null hypothesis that states the existence of a unit root and hence a non-stationary time series using t-test. A null hypothesis $\left(\mathrm{H}_{\mathrm{O}}\right)$ and alternative hypothesis $\left(\mathrm{H}_{1}\right)$ can be formed as follows:

$$
\begin{array}{ll}
\beta=1: \mathrm{H}_{0}, & \text { or } \beta=0 \\
\beta<1: \mathrm{H}_{1}, & \text { or } \beta<0
\end{array}
$$

Equation (1) is one of three instances in which a stationary time series is tested. The formula of the three cases is: (Time intersection and trend ) $\Delta \mathrm{Y}_{\mathrm{t}}=\alpha+\beta \mathrm{Y}_{\mathrm{t}-1}+\mathrm{Bt}+\mathrm{U}_{\mathrm{t}}$

(cross section) $\Delta \mathrm{Y}_{\mathrm{t}}=\alpha+\beta \mathrm{Y}_{\mathrm{t}-1}+\mathrm{U}_{\mathrm{t}}$

(Without cross section or trend) $\Delta \mathrm{Y}_{\mathrm{t}}=\beta \mathrm{Y}_{\mathrm{t}-1}+\mathrm{U}_{\mathrm{t}}$

A unit root hypothesis is refuted and hence a non-stationary time series. If the absolute value of $t$ is larger than the critical value, the alternative hypothesis (non-unit root) will be approved and hence a stationary time series. If the 
absolute value of $t$ is less than the critical value, the test should be carried out again with the first difference adopted in order to have a stationary time series (Guajarati \& Porter, 2009).

\subsection{Co-Integration Test}

The co-integration test, devised by Engel and Garner (1987), supports the economic theory by detecting correlations among economic variables within a statistical framework. From an economic perspective, some variables move regularly as time passes although they seem to be individually random. The co-integration test is, therefore, a prime instrument to look into the relations among economic variables in the long run. Furthermore, it helps identify the level of balance between stable and unstable data.

Co-integration is an association between two time series $\left(\mathrm{Y}_{1}, \mathrm{X}_{1}\right)$ or more where fluctuations in one of them causes stopping fluctuations in the other in a way that makes the rate between the two values fixed throughout time. Long-term relations across sets of variables prove helpful in predicting the assessment of dependent variables in terms of a set of independent variables. For it to happen, both series $\left(\mathrm{X}_{1}, \mathrm{Y}_{1}\right)$ must be separately an integration of order (1). Residual values resulting from estimating the relation between them are an integration of order zero. Therefore, co-integration requires meeting certain conditions. It is noticed that $\mathrm{V}_{1}$ in a random margin measures the regression of supposed relation in the short run from its balance trend in the long run.

Thus, co-integration is the statistic representation of a long-term balance relation. If there are two co-integrated variables, their relation is heading towards balance in the long run though with the possibility of deviations from this trend in the short run. For the test to be carried out, time series of the variables must be integrated of the same order. Results of data stability tests indicate that all the variables stand at the second difference, which means their integration of order (2), and that it is possible that there is a co-integration among the variables. The co-integration test is based on a null hypothesis that maintains the existence of $r$ or less within co-integration trends. Johansen devised two statistical tests to examine co-integration among a number of variables as follows:

1) Trace Test

2) Maximal Eigen Value Test

$$
\lambda_{\text {trace }}=-\mathrm{T} \sum_{i=r-1}^{n} \ln (1-\lambda i)
$$

$$
\lambda_{\max }=-\mathrm{T} \operatorname{Ln}\left(1-\lambda_{\mathrm{r}+1}\right)
$$

In which
T: number of observations;
$\mathrm{n}$ : number of variables;
$\lambda$ : estimated value of roots (Eigen values);
r: number of co-integration trends.

\subsection{Multiple Linear Regression Test}

A multiple linear regression test is the most commonly used instrument concerned with estimating the impact obtained from a quantitative variable, which is the dependent variable, and a set of other quantitative variables, being the independent ones. The outcome of this model is a linear statistic equation that may be used to interpret the relation between the dependent variable and independent variables, or estimating the value of the dependent variable if the values of the independent variables are known. Multiple linear regression analysis is concerned with examining and analyzing the impact of various independent variables on a dependent variable. Using more than one independent variable to interpret variance in the dependent variable, the degree of interpretation is increased. The stronger the independent variables used to measure multiple linear regressions with the dependent variable, the higher the degree of interpretation and vice versa. In the event of choosing independent variables, one should have a thorough knowledge of any indication to this correlation. Reference to previous research in this field was of outmost help to identify these variables. It should also be noted that each independent variable, though within a set of variables, functions in an incomplete way, i.e., it does not present an accurate interpretation that there are many factors that may play a part in this such as the relation between an independent variable with another one and how far this is related to the degree of interpretation. If that relation exists, what this variable interprets is based on the fact that it is included in the equation. Another factor that contributed to this interpretation is the relation of that variable with an independent variable or more.

\subsection{Validity Test Model}

This test was divided into three sub-tests to examine the validity of the first and second models. The three tests are Serial Correlation Test, Homogeneity Test, and Normal Distribution Test. 
4.6.1 Results of Statistical Analysis and First Model Hypothesis Test

\section{1) Results of Stationary Time Series Test for the First Model Variables}

Table 2. ADF test results for the first model (EG, PE, IN)

\begin{tabular}{cccc}
\hline Variable & Level & Value & Critical value at 5\% \\
\hline \multirow{2}{*}{ Inflation (IN) } & At the level & -4.01839 & -3.0294 \\
& First difference & -1.0021 & -2.0054 \\
Exports (X) & At the level & -3.0294 & 0.137236 \\
& First difference & -3.04 & 2.534504 \\
Public Expenditure (PE) & At the level & -3.02943 & 1.00661 \\
\multirow{2}{*}{ Economic Growth (EG) } & First difference & -3.04 & -2.5772 \\
& At the level & -3.0659 & -3.98439 \\
& First difference & -1.0541 & -1.8432 \\
\hline
\end{tabular}

Source: Researcher Data Collection E-VIEWS.

The data presented in table 2 above show that the value of inflation (IN) is higher than the table value at all statistic levels $(10 \%, 5 \%$, and $1 \%)$. Other variables were unstable. Therefore, the null hypothesis is refuted.

Considering the first differences for unstable variables at their levels, values appear statistically significant. $\mathrm{T}$ values are higher than those in table one at $1 \%, 5 \%$, and $10 \%$.

Upon performing the test again after including the first difference, these variables became stable. Consequently, the time series of the study were an integration of order (1). According to Engle and Granger (1987), in order to perform a co-integrated test, all variables must have the same stability as that which appears from the variables of the first model.

\section{2) Co-integration Test Results / First Model}

Table 3. Co-integration test results - first model (EG, PE, IN)

\begin{tabular}{ccccccc}
\hline $\begin{array}{c}\text { Number of Co-integration } \\
\text { Trends }\end{array}$ & $\begin{array}{c}\text { Eigen } \\
\text { value }\end{array}$ & $\begin{array}{c}\text { Trace } \\
\text { statistic }\end{array}$ & $\begin{array}{c}\text { Critical } \\
\text { value (5\%) }\end{array}$ & $\begin{array}{c}\text { Max Eigen } \\
\text { value }\end{array}$ & $\begin{array}{c}\text { Critical value } \\
(\mathbf{5 \% )}\end{array}$ & Prob** \\
\hline None* & 0.905643 & 67.80175 & 40.17493 & 44.85278 & 24.15921 & 0.0000 \\
At most 1 & 0.607124 & 22.94897 & 24.27596 & 17.75095 & 17.79730 & 0.0728 \\
At most 2 & 0.196103 & 5.198020 & 12.32090 & 4.147407 & 11.22480 & 0.5401 \\
At most 3 & 0.053794 & 1.050613 & 4.129906 & 1.050613 & 4.129906 & 0.3548 \\
\hline
\end{tabular}

Note. Trace test indicates 1 co-integration eqn equation(s) at the 0.05 level.

*denotes rejection of the hypothesis at the 0.05 level.

** Mackinnon - Haug - Michel's (1999) P- value

As appears from table 3, results show that there is a co-integration relation among the variables of the study of one trend and significance by $5 \%$ according to the Trace Test and Max Eigen Value Test.

It is therefore why the null hypothesis $\left(\mathrm{H}_{0}\right)$ is rejected while the alternative hypothesis $\left(\mathrm{H}_{1}\right)$, which signifies a co-integration, is accepted.

The number of co-integration trends is $r=1$ at a significant level of 0.05 . The results of data stability and co-integration tests entail a long-term relation among the variables of the study and hence a long-run equilibrium relationship. That is, they are likely to behave in the same manner in the long-run.

\section{3) Multiple Regression Analysis Results / First Model}


Table 4. Multiple regression analysis results / first model

\begin{tabular}{lcccc}
\hline \multicolumn{1}{r}{ Variable } & Coefficient & Std. Error & t-Statistic & Prob. \\
\multicolumn{1}{c}{ C } & 4.232867 & 0.402745 & 10.51003 & 0 \\
Pe & 0.292866 & 0.167306 & 1.750477 & 0.0992 \\
IN & -0.03756 & 0.016096 & -2.33319 & 0.033 \\
X & 0.270122 & 0.125452 & 2.153189 & 0.0469 \\
R-squared & 0.984953 & Mean dependent var & 8.629013 \\
Adjusted R-squared & 0.982132 & S.D. dependent var & 0.314412 \\
S.E. of regression & 0.042028 & Akaike info criterion & -3.32412 \\
Sum squared resid & 0.028261 & Schwarz criterion & -3.12497 \\
Log likelihood & 37.2412 & F-statistic & 349.1214 \\
Durbin-Watson stat & 1.24861 & Prob(F-statistic) & 0 \\
\hline
\end{tabular}

Source: researcher data collection E- Views.

Table 4 shows:

- A positive significant effect of PE on economic growth in Jordan. The t-value is 1.750477 with a statistical significance of 0.0992 , a positive value. The null hypothesis is rejected while the alternative hypothesis is accepted where public expenditure has a statistically significant effect on economic growth.

- There is a negative statistically significant effect of inflation (IN) on economic growth in Jordan. The t-value is -2.33319 with a statistical significance of 0.033 , a negative value. Thus, the null hypothesis is rejected in favor of accepting the alternative hypothesis that inflation has a statistically significant impact on economic growth.

- There is a positive statistically significant effect of exports (X) on economic growth in Jordan. The t-value is 2.153189 with a statistical significance of 0.0464 , a positive value. Thus, the null hypothesis is rejected and the alternative hypothesis is accepted where exports have a statically significant effect on economic growth.

Based on the F-Test, it is noticed that all independent variables have a statistically significant effect over the dependent variable. The F-value is 349.1214 with a statistically significant value of zero.

Based on the above analysis results, hypothesis test results of the first model are as follows:

- There is a positive statistically significant effect of public expenditure on economic growth. Thus, the first hypothesis is accepted.

- There is a positive statistically significant effect of exports on economic growth. The second hypothesis of the model is accepted.

- There is a negative statically significant effect of inflation on economic growth. The third hypothesis of the model is accepted.

\section{4) Validity Test Results / First Model}

- Serial Correlation Test

Table 5. Serial correlation test

\begin{tabular}{cccc}
\hline & \multicolumn{3}{c}{ Breusch-Godfrey Serial Correlation LM Test } \\
\hline F-statistic & 1.28668 & Probability & 0.306916 \\
Obs*R-squared & 3.105431 & Probability & 0.211672 \\
\hline
\end{tabular}

Source: Researcher data collection / E-Views.

The Breusch- Godfrey Serial Correlation LM Test is performed to test whether residuals are auto- correlative or not. $\mathrm{H}_{0}$ is when residuals are not auto-correlative. As shown in table 6 , the statistical significance is larger than $5 \%$. The null hypothesis $\left(\mathrm{H}_{0}\right)$ that residuals are not auto-correlative is rejected, i.e., the variance of the error margin values is fixed.

\section{- Homogeneity Test}


Table 6. Homogeneity test - White Heteroscedasticity test

\begin{tabular}{cccc}
\hline \multicolumn{4}{c}{ White Heteroskedasticity Test : } \\
\hline F-statistic & 1.599025 & Probability & 0.224435 \\
Obs*R-squared & 8.4926 & Probability & 0.204188 \\
\hline
\end{tabular}

Source: Researcher data collection / E-Views.

Normal Distribution

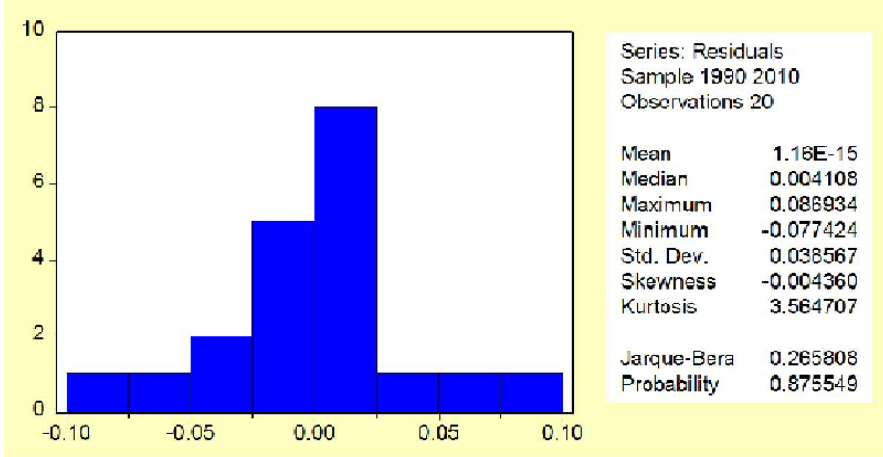

The White Heteroscedasticity Test was used to test that residuals are homogeneous or heterogeneous. $\mathrm{H}_{0}$ is where residuals variance is homogenous. As appears in Table 7, the significance level is larger than 5\%. The Null hypothesis $\left(\mathrm{H}_{0}\right)$ that residuals are homogenous is rejected. Homogeneous means that the variance between the error margin values is zero.

\section{- Normal Distribution Test}

Source: Researcher data collection / E-Views

$\mathrm{H}_{0}$ : Normal distribution residuals

$\mathrm{H}_{1}$ : Non-normal distribution residuals

If the probability is larger than 5\%, then the null hypothesis $\left(\mathrm{H}_{0}\right)$ is accepted and the alternative $\left(\mathrm{H}_{1}\right)$ is rejected.

The Normal Distribution Test was used to examine the residuals normal distribution. As appears from the table above, the Jarque-Bera value was 0.265808 with a significant level of 0.875549 . This entails the fact that $\mathrm{H}_{0}$ which states that residuals are normally distributed is accepted. The study concludes that all validity tests of the first model indicate that the model is accurate and valid.

4.6.2 Statistical Analysis Results and Hypothesis Test of the Second Model

\section{1) Stationary Time Series Test Results / Second Model}

Table 7. Dickey-fuller test results / second model (EG, PR, ED, ID)

\begin{tabular}{cccc}
\hline Variable & Level & Value & Critical Value at 5\% \\
\hline \multirow{2}{*}{ Public Revenues (PR) } & At level & 0.620887 & -3.0294 \\
& First Difference & -3.20599 & -3.04 \\
& At level & 1.149082 & -3.0294 \\
Internal Debt ( IN ) & First Difference & -1.13994 & -3.04 \\
& Second Difference & -3.51673 & -3.0521 \\
& At level & -2.51568 & -3.0294 \\
External Debt (ED) & First Difference & -4.55184 & -3.04 \\
& Second Difference & -6.0309 & -3.0521 \\
\multirow{2}{*}{ Economic Growth (EG) } & At level & -3.98439 & -3.0659 \\
& First Difference & -1.8432 & -1.0541 \\
\hline
\end{tabular}

Source : Researcher Data Collection / E- VIEWS.

Results show that the time series for public revenues (PR), internal debt (ID), and external debt (ED) are non-stationary. The test also indicates that the $\mathrm{t}$-values for each variable are less than the table values in their absolute value with a statistical significance at 5\%, based on lag (1). Accordingly, the null hypothesis (H0) points 
to an instability of the levels of the variables. Therefore, economic growth (EG) is stable with a critical value more extreme than would be at a significant level of 0.01 .

The first differences of unstable variables in their levels become significant. The t-values are larger than the table values with a significant level at 5\%. Upon performing the test another time, considering the first difference, these variables become stable. It follows, then, that the time series of the study variables are integrated at order (1). According to Engle and Granger (1987), in order to perform co-integration to perform the co-integration test, all variables must have the same stability level as is the case with the variables in the second model.

\section{2) Co-integration Test / Second Model}

Table 8. Co-integration test results / second model (EG, PR, ED, ID)

\begin{tabular}{ccccccc}
\hline $\begin{array}{c}\text { Number of } \\
\text { Co-integration Trends }\end{array}$ & Eigen Value & Trace Statistic & Critical Value (5\%) & Max Eigen Value & Critical Value (5\%) & Prob ** \\
\hline None & 0.742049 & 49.67351 & 47.85613 & 25.74474 & 27.58434 & 0.0334 \\
At most 1 & 0.506613 & 23.92877 & 29.79707 & 13.42277 & 21.13162 & 0.2035 \\
At most 1 & 0.386245 & 10.50600 & 15.49471 & 9.275014 & 14.26460 & 0.2438 \\
At most 1 & 0.062735 & 1.230989 & 3.841466 & 1.230989 & 3.841466 & 0.2672 \\
\hline
\end{tabular}

Source: Researcher data collection / E- Views.

Note. The Trace Test indicates 1 co-integration equation(s) at the 0.05 level.

* denotes rejection of the hypothesis at the 0.05 level;

** Mackinnon-Haug-Michelis (1999) P-values.

As is shown in Table 8, there is a co-integration relation among the variables of the study of one trend and a significance of 5\%, based on the Trace Test and the Max Eigen Value Test. The null hypothesis (H0) is therefore rejected and the alternative hypothesis that signifies co-integration is accepted. The co-integration trend number is $r=1$ at a significant level of 0.05 . Data stability and co-integration test results entail a long-run relationship among the variables and hence a long-term equilibrium relationship. They behave in the same way in the long run.

\section{3) Multiple Regression Analysis / Second Model}

In order to examine the study hypotheses, multiple linear regression analysis is adopted to explore the impact of independent variables on the dependent variable (economic growth) in the second model.

Table 9 shows the second model for testing the other three hypotheses.

Table 9. Multiple regression analysis results of the impact of the independent variables on the dependent variable (economic growth)

\begin{tabular}{|c|c|c|c|c|}
\hline Variable & Co-efficient & Std. Error & T-statistic & Prob \\
\hline $\mathrm{C}$ & 1.441257 & 2.017982 & 0.714207 & 0.4848 \\
\hline PR & 0.435855 & 0.116815 & 3.731166 & 0.0017 \\
\hline ED & 0.318562 & 0.232633 & -1.369373 & 0.1887 \\
\hline ID & 0.15876 & 0.095543 & -1.661663 & 0.0149 \\
\hline R-squared & 0.937908 & \multicolumn{2}{|c|}{ Mean dependent } & 8.655538 \\
\hline & 00.926951 & \multicolumn{2}{|c|}{ Var } & 0.329679 \\
\hline Adjusted R-squared & 0.089104 & \multicolumn{2}{|c|}{ S.D dependent Var } & -1.82838 \\
\hline S.E. of regression & 0.134973 & \multicolumn{2}{|c|}{ Akaike info criterion } & -1.62942 \\
\hline Sum Squared resid & 23.19795 & \multicolumn{2}{|c|}{ Schwarz criterion } & 85.59604 \\
\hline Long Likelihood & 0.874621 & \multicolumn{2}{|c|}{ F-statistic } & 0 \\
\hline Durbin-Watson Stat & 1.441257 & \multicolumn{2}{|c|}{ Prob ( F - statistic) } & 0.4848 \\
\hline
\end{tabular}

Source: Researcher Data Collection / E- Views.

Table 9 shows the following:

- There is a positive statistically significant effect of public revenues (PR) on economic growth in Jordan. The $\mathrm{t}$-value is 3.731166 with a statistic significance of 0.0017 , a positive value. The null hypothesis is rejected and the alternative of a statistically significant effect of public revenues on economic growth is accepted.

- There is a negative statistically significant effect of internal debt (ID) on economic growth in Jordan. The $\mathrm{t}$-value is -1.661663 with a statistic significance of 0.0149 , a negative value. The null hypothesis $(\mathrm{H} 0)$ is 
rejected and the alternative hypothesis (H1) of a statistically significant effect of internal debt on economic growth is accepted.

- There is no statistically significant effect of external debt (ED). The t-value is -1.369373 with a statistic significance of 0.1887 . The null hypothesis is accepted and the alternative is rejected.

- The t-value of the model is 85.59604 with a statistic significance of 0 , which is a value accepted statistically.

Based on statistical analysis results above, the hypothesis test results are as follows:

- There is a positive statistically significant effect of public revenues on economic growth. The first hypothesis is accepted.

- There is a negative statistically significant effect of internal debt on economic growth. The second hypothesis of the model is accepted.

- There is a negative non-statistically significant effect of external debt on economic growth. The third hypothesis of the model is rejected.

\section{- Serial Correlation Test}

Table 10. Serial Correlation test

\begin{tabular}{cccc}
\hline \multicolumn{4}{c}{ Breusch-Godfrey Serial Correlation LM Test } \\
\hline F-statistic & 0.504126 & Probability & 0.616274 \\
Obs* R-squared & 1.550174 & Probability & 0.460664 \\
\hline
\end{tabular}

Source: Researcher data collection / E-views.

The Serial Correlation LM Test was adopted to examine whether the residuals are auto- correlative or not. The null hypothesis (H0) is when residuals are not auto-correlative. As table 10 shows, the significance level is larger than $(5 \%)$. The null hypothesis that residuals are not auto-correlative is accepted. In other words, the variance of error margin values is fixed.

\section{- Homogeneity Test}

Table 11. Homogeneity test

\begin{tabular}{cccc}
\hline \multicolumn{4}{c}{ White Heteroscedasticity Test } \\
\hline F-statistic & 5.507428 & Probability & 0.004078 \\
Obs*R-squared & 14.75661 & Probability & 0.022288 \\
\hline
\end{tabular}

Source: Researcher data collection E-views.

The White Heteroscedasticity Test was adopted to examine whether residuals are homogeneous or heterogeneous. The null hypothesis (H0) is when the residuals are heterogeneous. As table 11 illustrates, the significance level is larger than 5\%. The null hypothesis (H0) that residuals are homogeneous is accepted. In other words, the variance among the error margin values is zero.

\section{- Normal Distribution Test}

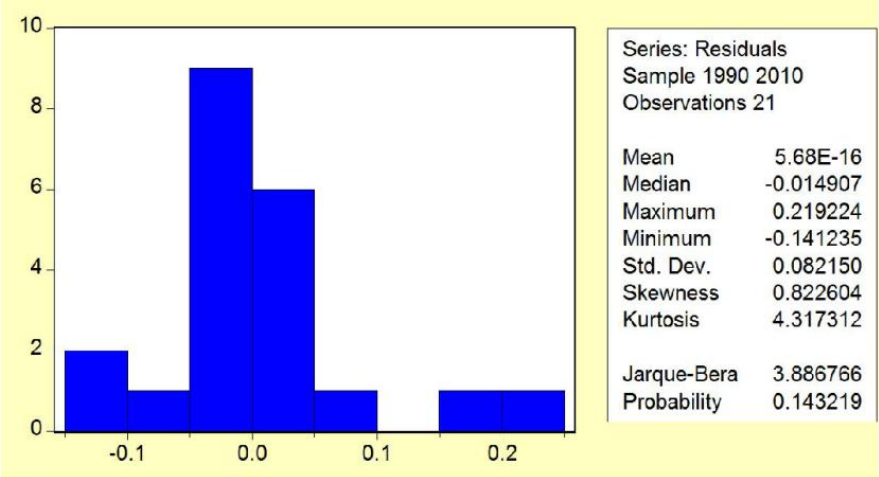

Source : Researcher data collection / E-views. 
H0: Residuals are normally distributed.

H1: Residuals are not normally distributed.

If the probability is larger than 5\%, then the null hypothesis is accepted and the alternative hypothesis is rejected. The Jarque-Bera Test was adopted to examine the normal distribution of the residuals. The table above shows that the Jarque-Bera value is 3.886766 with a significant level of 0.143219 . The null hypothesis that residuals are normally distributed is accepted. The study concludes that all tests used to examine the validity of the second model show that the model is accurate and reliable.

\section{Results Discussion}

- Results revealed a statistically significant impact of public expenditure on economic growth. An increase in public expenditure leads to an increase in economic growth. This is due to the fact that a high public expenditure, when coupled with a flexible and efficient production body, contributes to an optimal use of economic, human, financial, natural, and material resources. This, in turn, leads to an increase in income and GDP as a result of experienced exploitation of resources and production elements. An increase in public expenditure levels leads to an increase in income per capita as public expenditure is considered per capita income. An income increase means consumption increase and ultimately a high aggregate demand in economics. This urges economic institutions and projects to augment their production to meet a demand increase. Ultimately, employment will rise as well as the increase of more incentives for individuals to upgrade their efficiency at work. Income per capita will increase on the one hand while unemployment will drop on the other. All these results will reflect on the economic activity which will increase contributing to a rise in GDP (economic growth). The results agree with those of Matthew Kofi Ocran (2011), Shahid and Naved (2010), Chibi and Bin Bozian (2007), and Shokori (2007) in addition to an agreement with the hypotheses of the study.

- Results show a statistically significant impact of public revenues on economic growth; a rise in public revenues entails an increase in economic growth. The reason behind this is that public revenues are the key in any planning and policy-making process in economic and social development. If revenues are high, they will help increase spending on investment and employment activities, and they will refresh national economy. In addition, the volume of spending on future government activities depends on the volume of revenues. Thus, the process that public revenues carry out, as referred to earlier, relies directly on the volume of public revenues of the government. Public revenues have the same influence exerted by public expenditure, which shows the agreement of the results with those of Matthew Kofi Ocran (2011) and the hypotheses of the study.

- Results show a statistically significant impact of internal debt on economic growth, though a negative one. That is, the higher the internal debt is, the lesser the economic growth becomes. This is explained by the fact that a country's choice to pay internal debt through subscription from banks or individuals at a high interest rate in the market leads to what is called "crowding-out effect." As the volume of private investment is a function of the interest rate based on Keynesian theory, public debt ensues a drop in capital formation rate and economic activity in the private sector shrinks due to the government's crowding-out. As a result, private investment declines and a drop in the demand of private investment indicates a decrease in aggregate demand. This drop which is accompanied by a fixed aggregate supply generates a deflationary effect on the national level in which production and prices decrease that they ultimately bring about a decrease in the national production rate. In conclusion, the effect of internal debt is negative; a result which is consistent with that of Matthew Kofi Ocran (2011) and Shahid and Naved (2010) as well as the hypotheses of the study.

- Results show a statistically significant effect of external debt on economic growth, though negative. The higher the external debt is, the lesser the economic growth becomes. It is attributed to the fact that Jordan spends loans on consumptive spending rather than on productive spending which entails an overburden of external debt. Another result is that the government turns from spending these loans on productive income-generating projects that help create job opportunities and increase economic growth. This result corresponds with Matthew Kofi Ocran (2011), Shahid and Naved (2010), and the hypotheses of the study.

- Results show a statistically significant effect of exports on economic growth. The effect is positive where the more exports there are, the higher the economic growth is. This is accountable to the fact that an increase in exports increases aggregate demand, which eventually leads to a more aggregate supply to keep pace with the increase in demand. An increase in the number of workers will be needed as well as an increase in income, profits, and saving that will lead to high investment and economic growth. Moreover, an increase in exports yields an increase in foreign currency and enhances the status of the national currency by increasing its purchase power and hence economic growth. This result concurs with the hypotheses of the study. 
- Results show a statistically significant effect of inflation on economic growth, though negative. The higher the inflation is, the lesser economic growth becomes. The reason behind this is that when prices increase, aggregate demand drops and economic recession ensues. Recession leads to drops in production, exports, employment, GDP, and ultimately economic growth. Inflation creates a state of uncertainty over future developments, which affects and deters investment decisions. It also has adverse effects on motivations for saving, workers productivity, and enthusiasm because of low real income, and this ultimately leads to a drop in productivity and economic growth, especially in the case of hyperinflation. This result concurs with those of Shahid and Naved (2010) and the hypotheses of the study.

\section{Recommendations}

In light of the results, the study draws up a set of recommendations that may enhance the impact of fiscal policy tools on economic growth.

1) Increasing investment expenditure, decreasing consumption expenditure, and directing these expenditures to improve the infrastructure may attract investments, increase tourists and foreign currency towards a higher economic growth and alleviation of poverty and unemployment.

2) Increasing revenues and directing them to investment expenditures through a set of measures which are anti-corruption, an effective taxation policy that eliminates tax evasion, and new tax bases especially progressive taxes may generate a fair distribution of wealth and public reassurance. All these measures help increase public revenues in a way that does not affect the middle or lower class in Jordan.

3) Steering clear of internal and external debts because of their adverse effects on economic growth and resources except under certain circumstances when there is a need for internal or external debt can alleviate unemployment and create new investments and industries that can move economy forward and direct infrastructure to attract foreign investments and promote tourism. Debt decision makers in Jordan should use these loans rationally through directing them to huge investment projects in which revenues cover the service of this debt.

4) Upgrading the effectiveness of the fiscal policy through spending rationalization and increasing GDP.

5) Providing support to Jordanian exports, especially the leading ones, and exporting and expanding final goods rather than intermediate ones.

6) Reducing inflation which is considered a bane that needs the cooperation of all nations, whether developing or developed.

\section{References}

Abu Tayeh, S. N., \& Mustafa, M. (2011). The Determinants of Public Expenditures in Jordan. International Journal of Business and Social Sciences, 2(8).

Abu, N., \& Abdullahi, U. (2010). Government Expenditure and Economics in Nigeria (1970-2008). Business and Economics Journal (Vol. 2010, BEG-4).

Al- Essa, S. (n. d.). The Impact of Public Expenditure on Economic Growth in KSA, Kuwait, and UAE. M.A. dissertation.

Alfredo, P., \& Oriol, R. (2011). Long-term Effects of Fiscal Policy in Portugal. Journal of Economic Studies, 38(1), 114-127. https://doi.org/10.1108/01443581111096178

Al-wadi, M., \& Azzam, Z. (2000). Public Finance and the Financial System in Islam (p. 182). Amman: Al-Maysara Publishing House.

Amanja, D. M., \& Morrissy, O. (2005). Fiscal Policy and Economic Growth in Kenya. Center for Research in Economic Development and International Trade, University of Nottingham.

Askar et al. (1992). An Introduction to Research (p. 105). Amman.

Bader, M., \& Magableh, I. (2009). An Enquiry into the Main Determinants of Public Debt in Jordan: An Econometric Study. Dirasat Journal, Administrative Sciences, 36(1), 1-10.

Batayneh, K. (2009). Government Revenues and Expenditures: Causality Test for Jordan (pp. 1-13). Amman, Ministry of Planning and International Cooperation.

Ben Bouzian, M., Chibi, A., \& Shokori, S. M. (2007). Macroeconomic Effects of Fiscal Policy Shocks in Algeria: An Applied Study. Research paper, Faculty of Economics, Abi Bakr Bal Gayed University, Talmsan, Algeria.

Benos, N. (2009). Fiscal Policy and Economic Growth: Empirical Evidence from (EU) Countries. Paper provided 
by University Library of Munich, Germany (No. 19174).

Chibi, A., \& Bataher, S. (2010). Effective Fiscal Policy in Algeria: Analytical and Econometric Comparison. Development and Economic Policy Journal, 12(1), 37-39.

Darawsi, M. (2005). Fiscal Policy Role in Economic Balance: Algeria as a Model (1990-2004). Ph.D. dissertation. University of Algeria.

Daraz, H., \& Abu-Douh, M. (2005). Principles of Public Finance (pp. 45-47). Egypt: Al-Dar Al-Jami’ya.

Edgmon, M. (2002). Macroeconomics: Theory and Practice (p. 455). Translated by Ibrahim Mansour. Riyadh: AlMareikh Publishing House.

Gujarati, D. N., \& Porter, D. C. (2009). Basic Econometrics (5th ed.). New York. McGraw Hill Inc.

Helmi et al. (1999). Principles of Research on Economics, Finance, and Administration (p. 44). Amman: Safa for Publishing.

Hussein, W. (1988). Government Finance and Public Economy (p. 431). Alexandria.

Khalot, F. (2004). The Role of Fiscal Policy in Achieving Economic Stability and Growth in the Developing Countries under Current International Developments. M.A dissertation, Faculty of Law and Economics. Baskara: Mohammad Kheder.

Khateeb, K., \& Shamaileh, A. (2003). Public Finance Principles (1st ed., p. 24). Amman: Wael Publishing House.

Marouf, H. (2005). Macroeconomics Analysis (1st ed., p. 347 ). Amman: Safa' Publishing House.

Najjar et al. (2008). Research Methods. Amman: Al- Hamed Publishing House.

Nelson, C. R., \& Plosser, C. I. (1982). Trends and random walks in macroeconmic time series: Some evidence and $\begin{array}{lllll}\text { implications. Journal of } & \text { Monetary }\end{array}$ https://doi.org/10.1016/0304-3932(82)90012-5

Ocran, M. K. (2011). Fiscal Policy and Economic Growth in South Africa. Journal of Economic Studies, 38(5), 604-618. https://doi.org/10.1108/01443581111161841

Qabbor, N. A. (2008). The Role of Fiscal Policy on Economic Growth : Algeria as a Model (1994-2004). M.A. dissertation. Faculty of Economics, Farahat Abbas University, Algeria.

Shahid, \& Naved. (2010). Exploring the Dynamic Effects of Fiscal Policy in Macroeconomic Indicators: Time Series Evidence from Pakistan. Pakistan Institute of Development Economics, 49(4), 497-512.

Stock, J. H., \& Watson, M. W. (1989). New Indexes of Coincident and Leading Economic Indicators. NBER Macroeconomics Annual, 4, 351-409. National Bureau of Economic Research, Inc. https://doi.org/10.1086/654119

Wa, D. (2004). Public Expenditure and Economic Growth in Sri Lanka: Co-integration Analysis and Causality Testing. Staff Studies, 34(182), 51-68.

Wazani, K., \& Rifae, A. (2003). Macroeconomics: Theory and Practice (6th ed., p. 249). Amman: Wael Publishing House.

\section{Appendix 1}

\section{Terminology}

\section{Fiscal policy}

A fiscal policy is a set of policies regarding government revenues and public expenditures that achieve specific goals (Hussein, 1988, p. 431). According to others, it refers to the policy of exploiting public finance tools such as spending programs and government revenues to affect the macroeconomic variables of GDP, employment, saving, and investment to achieve goals and avoid undesirable results that might reflect on income GDP, GNP, employment, etc. (Al-wadi, Azzam, 2000, p. 182).

\section{Economic growth}

Economic growth is the annual increment represented as a ratio of GNP or GDP per individual. This standard reflects economic development and welfare.

It is also referred to as a long-term steady increase of per capital income (Edgmon, 2002, p. 455), and the ability of a country's economy to provide commodities and services within a specific period, whether nationally or 
internationally (Marouf, 2005, p. 347).

\section{Public revenues}

As a fiscal tool, public revenues are referred to as the total income earned by the government from different sources to cover expenses and achieve economic and social balance.

\section{Public expenditure}

Public expenditure is the money spent by either the country or a public corporate body to achieve a public interest.

\section{Exports}

Exports are the goods produced within the country and shipped overseas due to their abundance in the country and scarcity aboard. Exports value is a component of trade balance economic power.

\section{Inflation}

Inflation is a sustained noticeable rise in the general level of prices in a given country (Wazani, 2003, p. 249).

\section{Internal Public Debt}

Internal public debt is the loans borrowed by the government from a corporate body (natural or moral person) residing in the country, whether citizens or foreigners (Khateeb, 2003, p. 24).

\section{External Public Debt}

External public debt is the loans borrowed by the government from foreign governments, private institutions (banks), or international bodies such as the International Monetary Bank (IMF), the International Bank for Development, and the International Development Association (Daraz, 2005, pp. 45-47).

\section{Copyrights}

Copyright for this article is retained by the author(s), with first publication rights granted to the journal.

This is an open-access article distributed under the terms and conditions of the Creative Commons Attribution license (http://creativecommons.org/licenses/by/4.0/). 